\title{
LANGUAGE COMPETENCE OF POLYTECHNICAL NON- ENGINEERING GRADUATES NEEDED IN THE INDUSTRY WORLD
}

\author{
By \\ Sri Nur Yuliyawati ${ }^{1}$, Hazma $^{2}$ \\ ${ }^{1,2}$ Bandung State Polytechnic \\ Email: ${ }^{1}$ srinuryuli@polban.ac.id, ${ }^{2}$ hazma@polban.ac.id
}

\begin{tabular}{l}
\hline Article Info \\
\hline Articlehistory: \\
Received Nov 16, 2021 \\
Revised Dec 27, 2021 \\
Accepted Jan 26, 2022
\end{tabular}

Keywords:

Language Competence, Industry, Non-Engineering Majorss

\begin{abstract}
Changes in patterns, requirements, and competition for industrial workers have caused language lectures, both Indonesian and English courses, to be encouraged to prepare graduates from polytechnic non-engineering majors to have language competencies that are in line with industry needs. For this reason, a research was conducted on "Language Competence of Graduates of the Polytechnic NonEngineering Department Needed by the Business World and the Industrial World" which can be used as a reference for syllabus formulation and study material for language lectures. This study aims to describe the language competencies needed by the business world and the industrial world. To achieve this goal, the descriptive method is used with the data sources of this research consisting of resource persons, namely non-engineering alumni as well as the business and industrial world as well as curriculum documents of the Bandung State Polytechnic Department of Nonengineering, documents regarding KKNI, industrial competency references and language competencies. From this research, it is known that the language competencies needed by the industrial world are 1) writing competence for office administration activities: correspondence, making reports, designing activities/proposals, making agendas and meeting minutes, developing own ideas or other people's ideas; 2) speaking competence for presentations, telephone calls, communicating with relations, negotiating, and promoting; 3) the competence to read accurately, quickly and fluently to manage information, SOPs \& work instructions, company rules / regulations, process data accurately, and 4) listening competence to communicate and negotiate. These competencies are in accordance with the qualifications of the KKNI level 5 and 6 which must be possessed by polytechnic D3 and D4 graduates.
\end{abstract}

Thisisan open accessarticleunderthe CC BY-SAlicense.

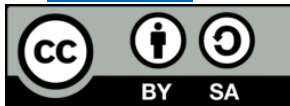

CorrespondingAuthor:

Sri Nur Yuliyawati,

Bandung State Polytechnic

Email: srinuryuli@polban.ac.id

\section{INTRODUCTION}

Competent human resources (HR) or those who behave behave; have knowledge, and skills according to industry standards are very much needed in winning the globalization of labor competition. The government's effort to produce competent human resources is the issuance of Presidential Regulation of the Republic of Indonesia Number 8 of 2012 concerning the Indonesian National Qualifications Framework (KKNI) and the implementation of industrial competency-based education programs. This is in parallel with Dunne's (1999) opinion which suggests that education contributes significantly if graduates are accepted in the business and industrial world. From his research at several universities with different disciplines in Australia, 81\% of the respondents think that the main goal of university education is for its alumni to be absorbed in the business world and the industrial world.

In order to produce competent human resources, the curriculum for the non-engineering polytechnic department must be aimed at preparing graduates who have competencies that are in line with the needs of the business world and the industrial world. Likewise, the curriculum or syllabus for language courses, both Indonesian and English courses, must be formulated to support graduates to have language competencies that are relevant to the 
business world and the industrial world. This is in line with the seven functions of language, namely: personal, regulatory, instrumental, representational, interactional, imaginative, and heuristic functions proposed by Halliday (Cholis, 2008) and the opinion that language is a medium for social interaction (Chaer, 1983). For this reason, graduates of non-engineering polytechnics majors need language competencies that are in accordance with the competencies of the industrial world, so it is necessary to conduct research on "Language Competencies of Graduates of Polytechnic Non-Engineering Departments Needed by the Business World and the Industrial World". Therefore, the purpose of this study is to describe the language competencies needed by the business world and the industrial world.

\section{Competence of the Business World and the Industrial World}

In the business world and the industrial world, competence is defined as a focused behavior in the workplace that includes the skills, knowledge, and performance observed in completing a job/task in accordance with industry standards. Factors that influence competence in industry are service, discipline, cooperation, achievement, leadership, proactiveness, and commitment to the organization (Spencer \& Spenser, 1993). Competence in the business world and the industrial world is needed to determine the right job for someone so that the company can help develop that person's competence through certain training. Thus, the competence of an employee will be a medium for the employee to show themselves and optimal performance for the company to know.

Competence in the Law of the Republic of Indonesia No. 13 of 2003 concerning Manpower, is defined as a criterion regarding a person's ability based on knowledge, skills, and behavior that is applied in the workplace that is oriented to the specified performance; work competence is the work ability of each individual which includes aspects of skills, knowledge, and behavior that are relevant to the standards set; work competency standards are formulations of abilities that must be mastered by individuals to carry out tasks or work based on knowledge, skills, and behavior in accordance with the specified performance.

Based on this description, it can be interpreted that work competence according to the Law of the Republic of Indonesia No. 13 of 2003 concerning Manpower is the ability and characteristics of a worker in the form of skills, knowledge, and behavior required in the duties of his position so that the worker can carry out his duties effectively, efficiently, as well as professionals. Competence can also be interpreted as a combination of knowledge/thinking with skills, behaviors, and actions in work that includes the ability to manage various tasks (task management skills), act accurately (contingency manager skills), work together (team work) and maintain a comfortable work environment, (job role environment skills) to adapt (transfer skills) to carry out routine tasks according to standards (task skills) that are actualized in life. (Kharhami, 2005; National Education Standards Agency, 2006; Munthe 2014).

\section{Language Competence}

Language is a medium for social interaction to express thoughts, ideas, concepts, or feelings (Chaer, 1983). Language is used by humans in all behaviors of life which are very broad and diverse so that language functions as much as the needs and acts of human behavior in life.

In a society, everyone communicates; sometimes as a listener and sometimes as a speaker. The process of changing from a listener to a speaker or vice versa is so natural, normal, and fast if the communication goes smoothly. The term "function" to indicate the nature of communication is used by Halliday (in Cholis, 2008). According to Halliday, language has an instrumental function (language moves and manipulates the environment and causes events to occur); function of regulation (language oversees events); Representational function (language for making statements, conveying facts and knowledge, explaining and reporting reality); Interactional function (language for social communication that requires knowledge of slang, jargon, jokes, folklore, customs, manners, and others); Personal function (language to express feelings, emotions, personality, reactions contained in the heart); functioning Heuristics (language to acquire knowledge); and Imaginative function (language for creating imaginary systems or ideas). Referring to these functions, that language competence is an important thing that determines the success of communicating between humans is something that cannot be denied.

In the field of linguistics, language competence is distinguished into active-receptive competence (ability to receive language) and active-productive competence (ability to produce language). Listening and reading are receptive-active competencies, while writing and speaking are active-productive competencies. Thus, listening, speaking, reading, and writing are oral and written language competence activities.

Listening competence is the skill of understanding spoken language that is receptive, not just listening to the sounds of language but at the same time understanding them. Speaking competence covers three types of speaking situations, namely interactive (face-to-face conversations and using the telephone), semi-active (speech in person), and non-interactive (speech via radio or television). Reading competence in the literacy community that has developed, is integrated with listening and speaking, although at first reading competence was separated from listening and speaking competence. Writing competence is not just copying words or sentences, but also developing 
International Journal of Social Science (IJSS)

Vol.1 Issue.5 February 2022, pp: 657-666

ISSN: 2798-3463 (Printed) | 2798-4079 (Online)

DOI: https://doi.org/10.53625/ijjss.v1i5.1308

and expressing thoughts or ideas in an orderly writing structure. Writing competence is the most complicated language competence.

Professions in politics, law (prosecutors, judges, and lawyers), public relations, and marketing are examples of fields of work that require language competence. How important is language competence in life. This can be exemplified in a manager. The position of manager will never be achieved if a person cannot convince the relevant authorities through his speaking and writing skills. A manager can manage the employees he leads and succeed if he has speaking competence which is also supported by listening, reading, and writing skills related to his profession.

Good language competence, of course, must be possessed by graduates of polytechnic non-engineering majors who will work in certain fields. Therefore, there should be language competence in the Competency Standards for Graduates from polytechnic non-engineering majors and in the Decree of the Minister of Manpower and Transmigration concerning the Determination of Indonesian National Work Competency Standards in the Office Administration Sector. Thus, language lectures in non-engineering majors must be focused on achieving the language competencies needed by the business world and the industrial world. It is undeniable that language competence is one of the important elements that determine successful communication in the business world and the industrial world.

\section{METHODS}

To achieve the formulated objectives, in this research descriptive method is used. The author believes that the use of the descriptive method is very relevant because it aims to describe the results of the study of the problem under study. To obtain relevant data, the data sources of this research consist of informants consisting of nonengineering alumni as well as the business and industrial world and documents consisting of curriculum documents for the Department of Police Non-engineering, references to KKNI, industrial competencies and language competencies.

To be relevant to the data source, data collection techniques in the form of library analysis, interviews, and observations were used. Literature analysis is used for data sources in the form of curriculum documents, the Decree of the Minister of Manpower and Transmigration concerning the Determination of Indonesian National Work Competency Standards in the Office Administration Sector, and references to other relevant research results in print and electronic mass media. Interviews and observations were used to obtain data on language competence from alumni of the non-engineering department and the business and industrial world. Interviews were conducted in person, online, and via electronic mail (e-mail) and observations were made at the offices of the two resource persons, namely the Permata Hijau Lestari office, Bogor and PT Bina FajarEstetika, Bandung.

Beginning with a literature review on the KKNI, industrial competence and language competence, this research begins. The next step is making interview and observation guidelines. Furthermore, interviews were conducted in person, online, and via electronic mail (e-mail) as well as observing employee activities in the office. Interviews and observations were carried out on non-engineering alumni as well as the business world and the industrial world as written in table 1 so that a description of the language competencies of non-engineering polytechnic graduates was obtained that was needed by the business world and the industrial world.

Table 1 Resource Person: Alumni and Industry Parties

\begin{tabular}{|l|l|}
\hline \multicolumn{2}{|c|}{ Alumni } \\
\hline Danil Hidayat & PT Telkomsel: Staff Call Center \& Partnership \\
\hline R. Mulyana & PT Infomedia Nusantara: Admin Support \\
\hline Indra Wahyudi & BRI Tower Bandung: Pelaksana Bisnis Mikro \\
\hline & Industry Parties \\
\hline
\end{tabular}

Journal homepage: https://bajangjournal.com/index.php/IJSS 


\begin{tabular}{|l|l|}
\hline $\begin{array}{l}\text { Muhammad Ulzi Muhammad, S. } \\
\text { Hum., M.Hum. }\end{array}$ & $\begin{array}{l}\text { Wijaya Karya (Persero) Tbk, Jakarta: Koordinator } \\
\text { General Affairs PT }\end{array}$ \\
\hline Pipih Zumatulafiah, Dra. & $\begin{array}{l}\text { CVPermata Hijau Lestari, Bogor: Ka. Administrasi dan } \\
\text { Keuangan CV }\end{array}$ \\
\hline Indra Komara, Ir. & CV Permata Hijau Lestari, Bogor: Direktur \\
\hline NoradwivaniNurulaini, S.E. & PT Wijaya KaryaRekayasakonstruksi: Stafsekretariat \\
\hline Muhamad UrfanNafis, S.S.T. & $\begin{array}{l}\text { PT Telkom Indonesia: Off 3 Planning Design an } \\
\text { instalasi relation }\end{array}$ \\
\hline Hadi Taufik, S. Ak. & PT MNC TelevisiNetwork: Deft Acc, Tax\& Billing, \\
\hline Alda Tabita & PT Bina FajarEstetika, Bandung: Staf Designer \\
\hline
\end{tabular}

\section{RESULTS AND DISCUSSION}

Referring to the description described in the research method, the following non-engineering graduates can describe the language competencies of non-engineering graduates.

Language Competence Competency Standards for Non-Engineering Polytechnic Graduates

One of the data sources for this research is the curriculum document of the Department of Police Nonengineering which consists of the curriculum document for the D4 Business Administration Study Program, D3 Business Administration, D4 Marketing Management, D3 Marketing Management, D4 Asset Management, D3 Travel Business, D4 Government Management Accounting, D3 Accounting, D4 Islamic Finance, and Banking Finance. Based on the analysis of the SKL in the study program curriculum document, it was found that there were 6 SKL majors in non-engineering supported by language competence, namely

1. Have the ability to communicate orally and in writing in Indonesian and English and have the ability to build relationships.

2. Have the competence to manage office and secretarial activities.

3. Have the skills to manage information and communication to support activities,

4. Presenting/promoting various things,

5. Write proposals/design activities,

6. Make reports/process data accurately.

Indonesian Language Competence for Business and Industry

The industry competency data related to the following language competencies are obtained from two sources. First, industrial competency data is obtained based on interviews and observations from the business world and the industrial world or service user agencies for non-engineering graduates and working alumni. Second, industrial competency data was obtained based on a literature review of the Decree of the Minister of Manpower and Transmigration Number: KEP.195/MEN/IV/2007 concerning the Stipulation of Indonesian National Work Competency Standards in the Corporate Services Sector, Other Enterprise Services Sub-sectors, in the Office Administration Service. Findings about this can be seen in the following table.

\begin{tabular}{l|l} 
Alumni Opinion & Industry Opinion
\end{tabular}


International Journal of Social Science (IJSS)

Vol.1 Issue.5 February 2022, pp: 657-666

ISSN: 2798-3463 (Printed) | 2798-4079 (Online)

\begin{tabular}{|l|l|}
\hline $\begin{array}{l}\text { Competencies related to Indonesian language } \\
\text { competence are: } \\
\text { coordination, explanation/submission of } \\
\text { analysis results, public speaking, } \\
\text { presentations, correspondence, report } \\
\text { generation, and administration. }\end{array}$ & $\begin{array}{l}\text { The language competence needed is writing a } \\
\text { letter, making a report }\end{array}$ \\
\hline $\begin{array}{l}\text { can listen tounderstand the condition of the } \\
\text { companylisten to presentations/deliver } \\
\text { company regulations or policies }\end{array}$ & $\begin{array}{l}\text { listen to understand, interpret the discussion of } \\
\text { a matter, and understand the content or written } \\
\text { and oral messages. }\end{array}$ \\
\hline $\begin{array}{l}\text { can speak during coordination, meeting, } \\
\text { presentation/explaining the company's new } \\
\text { provisions or regulations. }\end{array}$ & $\begin{array}{l}\text { can communicate politely, well, clearly, and } \\
\text { straightforwardly }\end{array}$ \\
\hline $\begin{array}{l}\text { can readSOPs\& work instructions } \\
\text { rulecompany termsinterpret the terms }\end{array}$ & $\begin{array}{l}\text { can read, understand the contents of analyze, } \\
\text { and make conclusions from the reading } \\
\text { correctly, fluently, and quickly }\end{array}$ \\
\hline $\begin{array}{l}\text { can write a report on the results of the visit, } \\
\text { results of program analysis, and letters }\end{array}$ & $\begin{array}{l}\text { can write information with effective sentences } \\
\text { and apply the rules of written language: } \\
\text { spelling/grammar, } \\
\text { ideas that will be conveyed to others, } \\
\text { other people's thoughts, } \\
\text { selecting, organizing, and documenting } \\
\text { information. }\end{array}$ \\
\hline
\end{tabular}

Based on the data in the table, the findings of language competence that are expected by non-engineering graduate service users by industry and agencies are language competence for students

a. writing a letter,

b. make a report,

c. interpret/understand the content or messages conveyed both orally and in writing,

d. presentation/delivering provisions/rules,

e. communicate well, politely, clearly, and straightforwardly,

f. Read, understand the contents of analyze, and draw conclusions from the reading correctly, fluently, and quickly: read SOPs \& work instructions, company rules/stipulations.

g. Write/develop other people's ideas and ideas with effective sentences and apply Indonesian Spelling rules.

h. Selecting, organizing, and presenting information.

Language Competence in the Industrial World according to the Decree of the Menakertrans

Based on the Decree of the Minister of Manpower and Transmigration of the Republic of Indonesia Number: KEP.195/MEN/IV/2007 concerning Stipulation of Indonesian National Work Competency Standards in the Corporate Services Sector Other Company Services Sub-sector in the Office Administration Services Sector, it was found that the competency findings in the office administration services sector were supported by language competence. as written in the following table.

Table 3 Work Competency Standards for Office Administration Services in the Decree ofMenakertransNomor :Kep. 195/MEN/IV/2007

\begin{tabular}{|c|l|l|c|c|c|c|}
\hline N & No Unit & \multicolumn{1}{|c|}{$\begin{array}{c}\text { Competency Unit: competency element } \\
\text { o }\end{array}$} & & \multicolumn{3}{|c|}{ Language Competence } \\
\cline { 4 - 7 } & & $\begin{array}{c}\text { listen } \\
\text { ing }\end{array}$ & speak & read & write \\
\hline 1 & ADM.P & apply basic communication skills & $\sqrt{ }$ & & $\sqrt{ }$ & $\sqrt{ }$ \\
& K01.001 & a. identify communication processes in the & & & & \\
\hline
\end{tabular}




\begin{tabular}{|c|c|c|c|c|c|c|}
\hline & .01 & $\begin{array}{l}\text { workplace } \\
\text { b. receive and convey information } \\
\text { c. conceptualize written communication as } \\
\text { information }\end{array}$ & & & & \\
\hline 2 & $\begin{array}{l}\text { ADM.P } \\
\text { K01.002 } \\
.01\end{array}$ & $\begin{array}{l}\text { communicate by phone: } \\
\text { a. receive phone calls } \\
\text { b. make a phone call } \\
\text { c. end and hang up the phone conversation } \\
\text { telephone message delivery }\end{array}$ & $\sqrt{ }$ & $\sqrt{ }$ & & \\
\hline 3 & $\begin{array}{l}\text { ADM.P } \\
\text { K01.003 } \\
.01\end{array}$ & $\begin{array}{l}\text { working with colleagues and customers: } \\
\text { communicating at work }\end{array}$ & $\sqrt{ }$ & $\sqrt{ }$ & & $\sqrt{ }$ \\
\hline 4 & $\begin{array}{c}\text { ADM.P } \\
\text { K02.007 } \\
.01\end{array}$ & $\begin{array}{l}\text { perform basic administrative procedures: } \\
\text { correspondence }\end{array}$ & & & $\sqrt{ }$ & $\sqrt{ }$ \\
\hline 5 & $\begin{array}{c}\text { ADM.P } \\
\text { K02.010 } \\
.01\end{array}$ & $\begin{array}{l}\text { take dictation to produce script: taking } \\
\text { notescreate a draft from a note-taking script }\end{array}$ & $\sqrt{ }$ & & $\sqrt{ }$ & $\sqrt{ }$ \\
\hline 6 & $\begin{array}{c}\text { ADM.P } \\
\text { K02.032 } \\
.01\end{array}$ & $\begin{array}{l}\text { design and manage meetings/meetings: } \\
\text { conduct questions and answers and attend } \\
\text { meetings }\end{array}$ & $\sqrt{ }$ & $\sqrt{ }$ & $\sqrt{ }$ & $\sqrt{ }$ \\
\hline 7 & $\begin{array}{c}\text { ADM.P } \\
\text { K02.033 } \\
.01\end{array}$ & make a presentation & $\sqrt{ }$ & $\sqrt{ }$ & & \\
\hline
\end{tabular}

When juxtaposed with the results of the competency analysis related to language competence in SKL majoring in non-engineering, the Industrial world, and the Decree of the Minister of Manpower and Transmigration, a comparison is obtained as shown in the following table.

Table 4 Comparison of Indonesian Language Competence Between SKL, the Industrial World, andSK Menakertrans

\begin{tabular}{|c|c|c|c|}
\hline no. & $\begin{array}{c}\text { competence based } \\
\text { onSKL }\end{array}$ & competency based on industry & $\begin{array}{c}\text { competence based on } \\
\text { Decree of Menakertrans }\end{array}$ \\
\hline 1 & $\begin{array}{l}\text { Have the competence } \\
\text { to manage office and } \\
\text { secretarial activities. }\end{array}$ & letter writing competence & $\begin{array}{l}\text { perform basic } \\
\text { administrative procedures: } \\
\text { correspondence }\end{array}$ \\
\hline 2 & $\begin{array}{l}\text { Have the ability to } \\
\text { communicate orally } \\
\text { and in writing in } \\
\text { Indonesian and } \\
\text { English and have the } \\
\text { ability to build } \\
\text { relationships. }\end{array}$ & $\begin{array}{l}\text { Competence to communicate } \\
\text { well, politely, clearly, and } \\
\text { straightforwardly } \\
\text { competence to } \\
\text { interpret/understand the content } \\
\text { or messages conveyed both } \\
\text { verbally and in writing }\end{array}$ & $\begin{array}{l}\text { apply basic communication } \\
\text { skills } \\
\text { a. identify communication } \\
\text { processes in the workplace } \\
\text { communicate by phone: } \\
\text { a. receive phone calls } \\
\text { b. make a phone call } \\
\text { c. end and hang up the } \\
\text { phone conversation } \\
\text { telephone message delivery } \\
\text { cooperate with colleagues } \\
\text { and customers: } \\
\text { communicate at work / } \\
\text { conduct questions and } \\
\text { answers in meetings }\end{array}$ \\
\hline 3 & $\begin{array}{l}\text { manage information } \\
\text { and communication }\end{array}$ & $\begin{array}{l}\text { competence in selecting, } \\
\text { organizing, and conveying }\end{array}$ & $\begin{array}{l}\text { a. apply basic } \\
\text { communication skills }\end{array}$ \\
\hline
\end{tabular}


International Journal of Social Science (IJSS)

Vol.1 Issue.5 February 2022, pp: 657-666

ISSN: 2798-3463 (Printed) | 2798-4079 (Online)

\begin{tabular}{|c|c|c|c|}
\hline & to support activities & information & $\begin{array}{l}\text { b. a. receive and convey } \\
\text { information } \\
\text { c. conceptualize written } \\
\text { communication as } \\
\text { information }\end{array}$ \\
\hline 4 & $\begin{array}{l}\text { presentation/ } \\
\text { promote things }\end{array}$ & $\begin{array}{l}\text { presentation } \\
\text { competence/delivering } \\
\text { provisions/rules }\end{array}$ & make a presentation \\
\hline 5 & $\begin{array}{l}\text { writing } \\
\text { proposals/designing } \\
\text { activities }\end{array}$ & & \\
\hline 6 & $\begin{array}{l}\text { make reports/process } \\
\text { data both accurate }\end{array}$ & competence to make reports & \\
\hline 7 & & $\begin{array}{l}\text { read, understand the contents of } \\
\text { analyze, and draw conclusions } \\
\text { from the reading correctly, } \\
\text { fluently, and quickly: read } \\
\text { SOPs \& work instructions, } \\
\text { company rules/stipulations. }\end{array}$ & \\
\hline 8 & & $\begin{array}{l}\text { writing competence/developing } \\
\text { ideas or ideas conveyed by } \\
\text { others with effective/good } \\
\text { sentences and using written } \\
\text { language rules (spelling) }\end{array}$ & \\
\hline 9 & & $\begin{array}{l}\text { Competence } \\
\text { writing/developing other } \\
\text { people's ideas and ideas with } \\
\text { effective sentences and } \\
\text { applying written language rules } \\
\text { (spelling/grammer). }\end{array}$ & $\begin{array}{l}\text { plan and manage } \\
\text { meetings/meetings }\end{array}$ \\
\hline 10 & & & $\begin{array}{l}\text { take dictation to produce } \\
\text { script }\end{array}$ \\
\hline
\end{tabular}

From the results of the analysis, the following points can be explained.

a. There are ten competencies related to Indonesian language competence, four of which, namely competencies no $1,2,3$, and 4 are competencies contained in the three data sources.

b. Competency no. 5 is only found in the SKL data source because the positions in the fields of work written in the SKL are higher than the positions of the resource persons, namely alumni and industry parties.

c. Competency no. 6 is only found in the SKL data source and the industry/service users, while in the Decree of the Minister of Manpower and Transmigration there is none. This is because in the Decree of the Minister of Manpower and Transmigration, the competencies that are formulated are only for one position, namely office administration services which do not or do not require competency no. the 6th.

d. Competency no. 7 and 8 show that more operational language competence is only found in industry and alumni resource persons; this is because the competence is the empirical experience of the resource persons.

e. Competency no. 9 and 10 are only found in the SK Menakertrans data source, this is because the positions addressed by these competencies are office administration services that indeed function to provide services to their superiors, while positions in the SKL and alumni data sources as well as industry parties are higher.

f. If viewed from the KKNI, the findings of Indonesian language competence based on the SKL and the industrial world are in accordance with levels 5 and 6 . This can be seen in the following table.

Table 5 Suitability of Language Competence with KKNI Qualifications Level 5 and 6

\begin{tabular}{|l|l|l|}
\hline 2 qualification & qualification level 6 & $\begin{array}{l}\text { language competence based on } \\
\text { SKL and the industrial world }\end{array}$ \\
\hline
\end{tabular}




\begin{tabular}{|c|c|c|}
\hline $\begin{array}{l}\text { able to complete a wide } \\
\text { range of work, choose the } \\
\text { appropriate method from a } \\
\text { variety of options that are } \\
\text { already or not standardized } \\
\text { by analyzing data, and able to } \\
\text { show performance with } \\
\text { measurable quality and } \\
\text { quantity }\end{array}$ & $\begin{array}{l}\text { - able to apply their field of } \\
\text { expertise and utilize science, } \\
\text { technology, and/or art in their } \\
\text { field in problem solving and } \\
\text { able to adapt to the situation } \\
\text { at hand }\end{array}$ & $\begin{array}{l}\text { 1. Have the competence to } \\
\text { manage office and } \\
\text { secretarial activities } \\
\text { 2. Have the ability to } \\
\text { communicate orally and in } \\
\text { writing in Indonesian and } \\
\text { English and have the } \\
\text { ability to build } \\
\text { relationships. } \\
\text { 3. Language competence to } \\
\text { be able to read, understand } \\
\text { the contents of analyze, } \\
\text { and make conclusions } \\
\text { from the reading correctly, }\end{array}$ \\
\hline $\begin{array}{l}\text { mastering the theoretical } \\
\text { concepts of certain fields of } \\
\text { knowledge both in general, } \\
\text { and able to formulate } \\
\text { procedural problem } \\
\text { solving. Able to manage } \\
\text { work groups and compile } \\
\text { written reports both } \\
\text { comprehensively }\end{array}$ & $\begin{array}{l}\text { - mastering the theoretical } \\
\text { concepts of certain fields of } \\
\text { knowledge, both general and } \\
\text { the theoretical concepts of } \\
\text { special sections in the field of } \\
\text { knowledge, both in depth, } \\
\text { and able to formulate } \\
\text { procedural problem solving }\end{array}$ & $\begin{array}{l}\text { - language competence to } \\
\text { present and promote various } \\
\text { things } \\
\text { - language competence to } \\
\text { design activities/plan and } \\
\text { manage meetings/meetings } \\
\text { - Indonesian language } \\
\text { competence to make } \\
\text { reports/process data both } \\
\text { accurately }\end{array}$ \\
\hline $\begin{array}{l}\text { responsible for their own } \\
\text { work and can be given } \\
\text { responsibility for the } \\
\text { achievement of group work } \\
\text { results }\end{array}$ & $\begin{array}{l}\text { - able to make good decisions } \\
\text { based on analysis of } \\
\text { information and data, and } \\
\text { able to provide guidance in } \\
\text { choosing various alternative } \\
\text { solutions both independently } \\
\text { and in groups. }\end{array}$ & $\begin{array}{l}\text { language competence to write / } \\
\text { develop ideas and ideas of } \\
\text { others / dictation with effective } \\
\text { sentences and apply the rules } \\
\text { of written language (spelling / } \\
\text { grammar). }\end{array}$ \\
\hline & $\begin{array}{l}\text { - be responsible for their own } \\
\text { work and can be given } \\
\text { responsibility for the } \\
\text { achievement of the } \\
\text { organization's work results. }\end{array}$ & \\
\hline
\end{tabular}

The formulation of Indonesian language competence which is in line with the competence of the industrial world supports Chaer's (1983) opinion that language is a medium for communicating ideas, thoughts, concepts, or feelings which is termed social interaction media. In addition, the formulation describes the six language functions found by Halliday (in Cholis, 2008) except for the imaginative function which is not reflected.

In language competence that is in line with SKL and competence in the industrial world, five competency characteristics have been included, namely motives, traits, self-concepts, knowledge, and skills as stated by Gordon in Munthe (2014) and the opinion of Spencer \& Spencer (1993) so that they must be taught to students. Nonengineering polytechnic majors in language courses. Another reason, the importance of these competencies being taught to students majoring in non-engineering polytechnics is due to the current function of language as a medium for expressing various modern ideas as suggested by Sugono (2007).

Findings of language competencies that are in line with SKL and competencies of the business and industrial world can be used as reference material for formulating study materials. This is because in the process of using it/learning students will learn language competence instead of learning linguistics so that it can overcome the lack of students' Indonesian language skills as written in a scientific article entitled "Competency-Based Indonesian Learning". In the article, Widyaiswara Muda, Palembang Religious Education and Training Center, Hodidjah (2015) wrote "The Indonesian language ability of students is still a concern, even at the university level. For this reason, it is recommended to emphasize learning Indonesian on the use of language, not on language theory." In addition, the reasons for these findings can be used as reference material for formulating study materials in line with those proposed by Suparti (2006). 
International Journal of Social Science (IJSS)

Vol.1 Issue.5 February 2022, pp: 657-666

ISSN: 2798-3463 (Printed) | 2798-4079 (Online)

DOI: https://doi.org/10.53625/ijjss.v1i5.1308

Language learning aims to achieve communicative competence, namely the competence to use language as a basis in thinking and acting activities to understand and interpret life both individually and socially. Communicative competencies include: listening, speaking, reading, and writing competencies based on critical and creative thinking competencies. Competency-based Indonesian language learning is an alternative to realizing communicative competence, and teachers are expected to be able to develop it in accordance with existing principles and procedures.

\section{CONCLUSION AND SUGGESTIONS}

From the analysis of the data obtained, it can be concluded that the language competencies of nonengineering polytechnic graduates needed by the business and industrial world are 1) writing competence for office administration activities: correspondence, making reports, designing activities/proposals, making agendas and meeting minutes, developing ideas own or the ideas of others; 2) speaking competence for presentations, telephone calls, communicating with relations, negotiating, and promoting; 3) the competence to read accurately, quickly and fluently to manage information, SOPs \& work instructions, company rules / regulations, process data accurately, and 4) listening competence to communicate and negotiate.

In the formulation of language competencies that are in line with SKL and the competencies of the business world and the industrial world, it is illustrated that even in the business world and the industrial world, language is a medium for communicating ideas, thoughts, concepts, or also feelings which are termed social interaction media. These competencies are in accordance with the qualifications of the KKNI level 5 and 6 which must be possessed by polytechnic D3 and D4 graduates.

Referring to these conclusions, it is recommended that language lecturers formulate a syllabus and also make study materials that refer to the standard language competence of graduates and the competence of the business world and the industrial world so that it will motivate students to take language courses because students are aware that they will gain the necessary increase in language competence in the world of education. Business and industry.

\section{REFERENCE}

[1] National Education Standards Agency. 2006. Graduate competency standard document. Jakarta: National Education Standards Agency.

[2] Chaer, A. 1983. General linguistics. Jakarta :RinekaCipta.

[3] Cholis, N. and Avianto, Y. 2008. Principles of language learning and teaching.(by H.Douglas Brown) Jakarta: Embassy of the United States of America.

[4] Ministry of Education. 2008. Big Indonesian Language Center Language Dictionary. Jakarta: Gramedia.

[5] Dunne, E. 1999. The learning society, international perspectives on core skills in higher education. London: Kogan Page.

[6] Hodidjah. 2015. "Competency-based Indonesian language learning" (Online). Accessed from http://bdkpalembang.kemenag.go.id/pembelajaran-Bahasa-indonesia-berbasis-kompetensi/. (26 Agustus 2021)

[7] Kharhami, K.A. 2005. "Competence". in the Bulletin of the Book Center, vol. 11 January-June.

[8] Attachment to Regulation of the Minister of National Education Number 23 of 2006 Dated May 23, 2006 "Concerning Graduate Competency Standards (SKL)". (On line). Accessed from http://staff.unila.ac.id/radengunawan/files/ 2011/09/ Permendiknas- No.-23-tahun-2006.pdf. (17 juli 2021)

[9] Munthe, B. 2014. Learning design. Jogjakarta: Civil Society Library.

[10] Permendiknas No. 23 of 2006 concerning "Graduate Competency Standards".

[11] Regulation of the Minister of Manpower and Transmigration of the Republic of Indonesia Number 8 of 2012 concerning procedures for determining Indonesian national work competency standards.

[12] Presidential Regulation of the Republic of Indonesia Number 8 of 2012 concerning Indonesia's National Qualification Framework (documents on electronic media). (On line). Accessed from http://qa.its.ac.id/id/wpcontent/uploads/Lampiran-8-2012-KKNI.pdf.(17 juli 2021)

[13] Spencer, L.M. \& Spencer, S.M. 1993. Competence at work, models for superior performance. John Willey \& Sons Inc. Stoner,

[14] Suparti. 2006, March. "Competency-based Indonesian language learning". Journal of Didactics, Vol. 1 No.1 p. 57-64 . (On line). Accessed from https://utsurabaya.files.wordpress.com/2010/08/supart1-pemb-indonesiakbk.pdf. (16 Juni 2021) 
